\title{
The Chinese Insurance Market: Estimating its Long-Term Growth and Size*
}

\author{
Wei Zheng ${ }^{\mathrm{a}}$, Yongdong Liu ${ }^{\mathrm{b}}$ and Gerry Dickinson ${ }^{\mathrm{c}}$ \\ ${ }^{a}$ School of Economics, Peking University, Beijing 100871, P.R. China. \\ E-mail: weizhengpku@yeah.net \\ ${ }^{\mathrm{b}}$ Center for Chinese Agricultural Policy, Institute of Geographical Sciences and Natural Resources, Chinese \\ Academy of Sciences, Beijing 100101, P.R. China \\ ${ }^{\mathrm{c}}$ Cass Business School, City University, London, 106 Bunhill Row, London EC1Y 8TZ, UK. \\ E-mail: gerry@franetwork.com
}

The mid-term and long-term growth potential of China's insurance industry is a subject of significant interest to governments, business and academia. In this paper, the "world insurance growth curve" is used in conjunction with estimates of China's future GDP growth to estimate the growth and size of China's insurance industry for the period 20062020. There are clearly other factors - social, political, cultural, demographic and market structure - that also have an impact, but other empirical studies have shown that the key factor in the long term is growth and development of the overall economy. Assuming that China's GDP grows over that period at a rate of 6-9 percent per year, we conclude that the possible range of China's insurance industry growth rate would be 7.7-17.9 percent, with a more likely range of 9.8-14.8 percent. In the median scenario, the average annual real growth rate for China's insurance industry during the period 2006-2020 would be 12.3 percent. Thus, by the year 2020, the size of China's insurance market would be 5.7 times of that of 2005, and the overall insurance penetration would be 5.6 percent, with 4 percent for life insurance and 1.6 percent for non-life insurance. The growth rate of China's insurance industry during the period 2006-2020 would be almost double the world average and by 2020, China's share of the world insurance market would be about 4.0 percent.

The Geneva Papers (2008) 33, 489-506. doi:10.1057/gpp.2008.19

Keywords: China's insurance industry; mid- and long-term; growth potential; world insurance industry

Jel classification: E27; G10; O16

\section{Introduction}

There is a marked difference of opinion among economists regarding the medium- and long-term growth potential of China's insurance industry. According to many, China's

\footnotetext{
* This article was presented at "Beida CCISSR Forum 2006", "CCISSR Biweekly Seminar", "PKU Economics Lunch Seminar" and “APRIA 2006" (Tokyo Japan). The participants' comments are appreciated; in particular, we benefited from Professor Qixiang Sun, Professor Xinyu Li, Professor Zhiwei Wang, Professor Shaorong Li, Dr. Dong Chen, Dr. Zhiyong Dong and Dr. Qingjie Xia. We would like to give special thanks to Dr. Rudolf Enz for his valuable correspondence and communications, and Swiss Re (especially Mr. Clarence Wong) for providing research data. We also thank Ms. Yiting Deng for her help in proofreading and Dr. Derek Atkins for his helpful comments on the presentation.
} 
insurance industry has tremendous growth potential and as a result has witnessed an influx of international insurances companies. On the other hand, some data have suggested a decline in the growth rate of China's insurance industry, accompanied by a sharp increase in market competition, and even a tendency towards market saturation in some areas. It is this huge discrepancy that inspired us to carry out this study. This paper aims to settle those disputes by a quantitative analysis of the growth potential of China's insurance industry over the period 2006-2020. There are clearly a variety of factors - economic, social, cultural, political, demographic and market structure that have an impact on the growth of the insurance industry, but empirical studies have shown that the key factor in the long term is overall size of the economy. ${ }^{1}$ Hence, the focus in the paper is on GDP growth as the key driver of insurance market growth.

A widely applied method in the estimation of the growth potential of China's insurance industry is the "International Average Method". For example, economists often compare China's insurance penetration directly with the global average penetration. ${ }^{2}$ Although reasonable to some degree, this method is inevitably restricted by some shortcomings. First, it neglects the important fact that countries at different stages of economic development have different levels of insurance penetration. Another point worth mentioning is that it is the GDP per capita, not the GDP that indicates a country's development stage or its insurance penetration. For example, China's GDP has recently been ranked among the highest in the world, while China's per capita GDP is still remarkably low (ranked about the 100th in the world). Therefore, if China's insurance penetration during the period 2006-2020 is calculated on the basis of China's GDP per capita (which is far below the world average level), then it would fall below the world average level as well. Thus, by using the "International Average Method", the growth potential of China's insurance industry is often overestimated, thereby misleading the policymakers.

Three points about this paper should be noted in particular. First, instead of applying the standard "international average method", it uses the "world insurance growth curve". Second, based on the world insurance growth curve, a new indicator "Benchmark Ratio of Insurance Penetration (BRIP)" is defined, which takes into account other information about a country's national economy and insurance development and is more effective in measuring the mid-term and long-term insurance growth potential of a country. Third, during the period 2001-2005, China's insurance industry experienced wide fluctuation; thus the expectations for the future of China's insurance industry are uncertain. This study on China's insurance growth potential during the period 2006-2020 could serve as a theoretical basis for making industrial policies.

The paper is organized as follows: The following section introduces the research background, motives and aims. In the next section, we use a large amount of historical

\footnotetext{
${ }^{1}$ See Beenstock et al. (1986, 1988); Outreville (1996).

${ }^{2}$ For instance, the global average insurance penetration was about 8 percent in 2005 ; so in line with this penetration level, as well as the fact that China's GDP was 18,232.1 billion Yuan in 2005, China's total insurance premium would be $1,458.57$ billion Yuan. However, China's total insurance premium is actually 492.73 billion Yuan, so that it is concluded that there is great potential for China's insurance industry, since China's current premium is only 34 percent of the level it should be at.
} 
data to estimate the "world insurance growth curve". The following section outlines the assumptions we make about China's GDP, BRIP, price index and exchange rate. In the next section, based on the world insurance growth curve, and data on China's national economy and China's insurance industry, we calculate the mid- and long-term (2006-2020) growth potential for China's insurance industry under the approach of

"Market Exchange Rate". In the subsequent section, combining the "Market Exchange Rate" method as well as the "Purchasing Power Parity (PPP)" method, we make a modification to the previous calculation. In the penultimate section, we estimate the size of China's insurance industry by 2020. The final section draws conclusions and provides some additional explanations.

\section{World insurance growth model}

\section{Model setup}

Generally speaking, there are currently three different types of insurance growth models available: the first type is the simple linear model, the second is the logarithmic linear model and the third is the logistic model. Each has its own advantages and disadvantages, but comparatively, the logistic model is superior to the first two models for this research.

Under the simple linear model and logarithmical linear model, no matter whether premium, insurance density or insurance penetration is chosen as the dependent variable, and no matter whether it is a simple linear equation with GDP or GDP per capita as independent variable, or a multi-linear equation taking into account other economic or social indicators, limitations are obvious. With regard to the simple linear model, it is always assumed that: (1) insurance premium grows at the same rate with the growth of GDP, which indicates that insurance penetration is a constant; or (2) insurance premium grows at a rate that is the square of that of GDP growth. Neither of these assumptions is consistent with the reality. With regard to the logarithmic linear model, it is often assumed that: (1) the income elasticity of premium (the ratio of the percentage change in insurance premium to the percentage change in GDP) is a constant; and (2) the income elasticity of penetration (the ratio of the percentage change in insurance penetration to the percentage change in GDP) is a constant. While these two assumptions are probably acceptable in certain stages of economic development, they cannot be applied in a general model.

What is the relationship between a country's premium and the economy? As is illustrated in Figures 1 and 2, the insurance penetration (the ratio of the premium to the GDP) rises with the GDP per capita, but different levels of GDP per capita are accompanied by different growth rates of insurance penetration. When the level of the GDP per capita is low, the growth rate of insurance penetration is relatively slow. As the GDP per capita increases, the growth rate of insurance penetration increases as well. However, after the GDP reaches a certain level, the insurance penetration tends to plateau. This means, with the increase of the GDP per capita, that the growth rate of premium will exceed that of the GDP per capita. The gap of the two growth rates is smaller when the GDP per capita is low, and expands with the growth of GDP per capita, but will eventually narrow after a certain stage. In other words, the income 


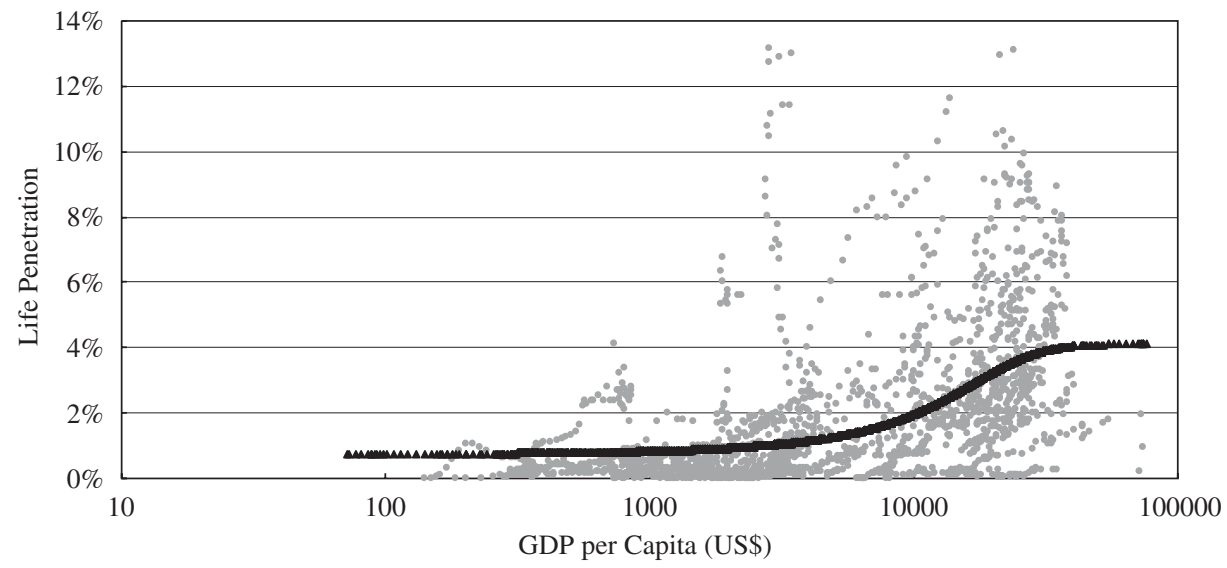

Figure 1. Relationship between life penetration and GDP per capita.

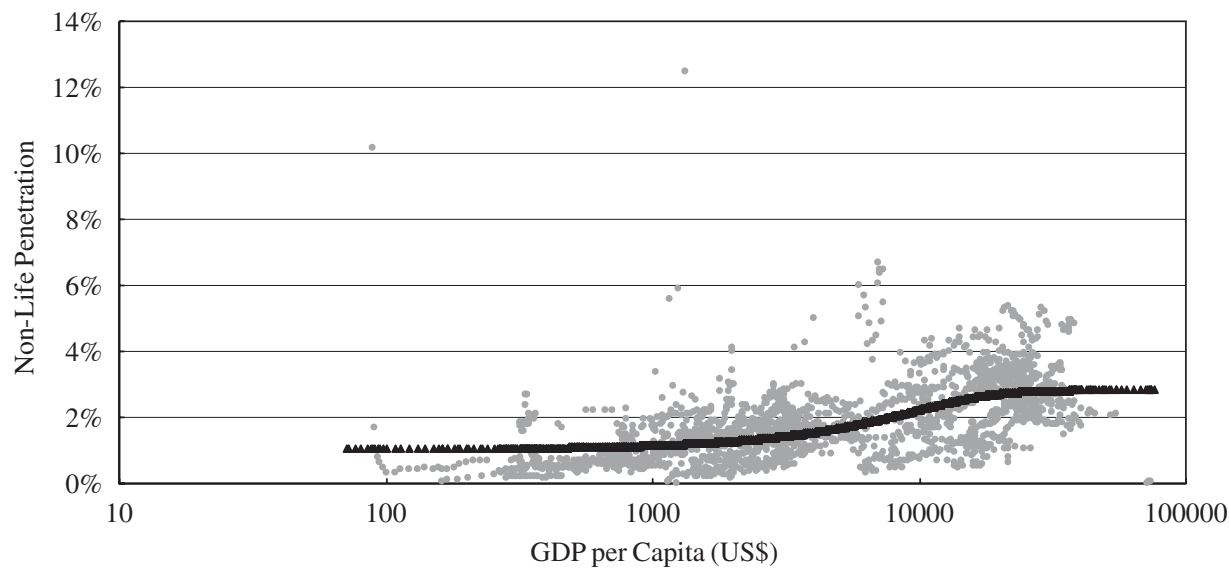

Figure 2. Relationship between non-life penetration and GDP per capita.

elasticity of premium varies with the stage of economic development. A logistic model, which is often in the shape of the letter "S", will better characterize this phenomenon.

Carter and Dickinson ${ }^{3}$ and $\mathrm{Enz}^{4}$ developed a logistic model to depict the relationship between insurance penetration and GDP per capita. Because the logistic curve is in the shape of the letter "S", the model is called "the S-curve model" for short. Based on this model, this paper will estimate the world insurance growth curve with a large amount of historical data.

\footnotetext{
${ }^{3}$ Carter and Dickinson (1992).

${ }^{4}$ Enz (2000).
} 
The expression of the S-curve model is as follows:

$$
Y=\frac{1}{C_{1}+C_{2} C_{3}^{X}}+\varepsilon
$$

where $Y$ is the insurance penetration, $X$ is the GDP per capita, $C_{1}, C_{2}$ and $C_{3}$ are three parameters and $\varepsilon$ is the residual term. ${ }^{5}$

\section{The sample data}

This paper uses the data of 95 countries and districts over the past 27 years (1980-2006) as the sample. There are 2,052 observations in the sample of life insurance, and 2,071 observations in the sample of non-life insurance. The data of GDP, population and GDP per capita for each country and district come from the National Accounts Main Aggregates Database provided by the United Nations. The data on total premium, life premium, non-life premium, life penetration and non-life penetration are taken from the Sigma database provided by Swiss Re. Data on GDP per capita are converted to constant 1990 prices in US\$, and the penetration which is a relative ratio (Premium/GDP) is not affected by the price level.

Based on the data, we can either carry out a total industry estimation without distinguishing life and non-life insurance, or carry out two estimations for life and non-life, respectively. In consideration of the different characteristics of life and non-life insurance, however, we will prefer the latter option and separately estimate the models for world life and non-life insurance growth curves, which will be much more precise than an entire-industry estimation. Models are estimated by pooled Nonlinear Least Square. In addition, in the data used by this paper, the catalog of life insurance and non-life insurance follows the practice of the EU and OECD, in which health insurance and accident insurance are all counted as nonlife insurance.

\footnotetext{
${ }^{5}$ It is assumed that $C_{3}<1$, because $C_{3}<1$ means that the penetration increases as the GDP per capita rises. Meanwhile, $C_{3}=1$ means the penetration is a constant, and does not change as the GDP per capita changes; $C_{3}>1$ means the penetration decreases as the GDP per capita rises. The last two situations are not consistent with the reality; therefore, it is assumed that $C_{3}<1$ in this paper. Using the equation of the model, we can find the inflexion of the S-curve (the increasing rate of penetration increases before this point and decreases thereafter). It is at this point that the second derivative equals 0 . That is, $Y^{\prime}=-\left(C_{1}+C_{2} \cdot C_{3}^{\wedge} X\right)^{-2}\left(C_{2} \cdot C_{3}^{\wedge} X \cdot \ln C_{3}\right)$ and $Y^{\prime \prime}=2\left(C_{1}+C_{2} \cdot C_{3}^{\wedge} X\right)^{-3}\left(C_{2} \cdot C_{3}^{\wedge} X \cdot \ln C_{3}\right)^{2}-\left(C_{1}+C_{2} \cdot C_{3}^{\wedge} X\right)^{-2}$ $\left(C_{2} \cdot \ln C_{3} \cdot C_{3}^{\wedge} X \cdot \ln C_{3}\right)$. Because $Y^{\prime \prime}=0$, the exact form of the GDP per capita (denoted by $\left.X_{\text {inf }}\right)$ at the inflexion is calculated as: $X_{\text {inf }}=\left(\ln C_{1}-\ln C_{2}\right) / \ln C_{3}$. According to the model, it is not difficult to obtain the income elasticity of premium (the ratio of the percentage change in insurance premium to the percentage change in GDP) in terms of $e$. Denote $P$ as the premium per capita, then we have: $e=(\mathrm{d} P / P) /$ $(\mathrm{d} X / X)=(\mathrm{d} P / X) /(X / P)$. Since $Y=P / X=\left(C_{1}+C_{2} \cdot C_{3}^{\wedge} X\right)^{-1}, P=X \cdot\left(C_{1}+C_{2} \cdot C_{3}^{\wedge} X\right)^{-1}$, the income elasticity of premium is calculated as: $e=1-\left(C_{2} \cdot C_{3}^{\wedge} X \cdot X \cdot \ln C_{3}\right)\left(C_{1}+C_{2} \cdot C_{3}^{\wedge} X\right)^{-1}$. Furthermore, the maximum income elasticity of the premium can be obtained. As at the maximum point, the first derivative of $X$ equals 0 , that is, $e^{\prime}=0$, the expression of GDP per capita (denoted by $X_{e}$ ) corresponding to the maximum income elasticity of premium is as follows: $1+X_{e} \ln C_{3}+\left(C_{2} \cdot C_{3}^{\wedge} X_{e}\right) / C_{1}=0$.
} 
Table 1 Estimates of world life and non-life insurance growth model

\begin{tabular}{lcc}
\hline & Life insurance & Non-life insurance \\
\hline$C_{1}$ & $24.37^{* * *}(16.59)$ & $35.45^{* * *}(47.53)$ \\
$C_{2}$ & $111.03^{* * *}(12.83)$ & $62.72^{* * * *(19.93)}$ \\
$C_{3}$ & $0.8671^{* * *}(68.14)$ & $0.8276^{* * *}(51.46)$ \\
$R^{2}$ & & \\
Adjusted- $R^{2}$ & 0.5362 & 0.8115 \\
Number of observations & 0.5356 & 0.8112 \\
GDP per capita at the inflexion (1990 US\$) & 2,052 & 2,071 \\
Maximum income elasticity of premium & 10,635 & 3,015 \\
GDP per capita at the maximum elasticity (1990 US\$) & 1.754 & 1.425 \\
\hline
\end{tabular}

Note: Robust $t$-statistics is in parentheses. The term of "***" means that the level of significance is 1 percent.

\section{Estimations using the model}

Table 1 shows the estimates of the world life and non-life insurance growth model. According to these estimates, we then calculate the world life insurance growth curve and the world non-life insurance growth curve (the S-curves as referred to above), which are respectively depicted in Figures 1 and 2.

First, consider the world life insurance growth model. Before GDP per capita reaches 10,635 US\$, the growth rate of life penetration keeps increasing. After GDP per capita exceeds 10,635 US\$, the growth rate slows down. When GDP per capita is 12,438 US\$, the income elasticity of premium achieves the maximum level of 1.754. This figure means that if GDP per capita increases by 1 percent, then premium per capita will increase by 1.754 percent.

Then we analyze the world non-life insurance growth model. Before GDP per capita reaches 3,015 US\$, the growth rate of life penetration keeps increasing. After GDP per capita exceeds 3,015 US\$ the growth rate slows down. When GDP per capita is 7,531 US\$, the income elasticity of premium achieves the maximum level of 1.425. This figure means that if GDP per capita increases by 1 percent, then premium per capita will increase by 1.425 percent.

\section{Assumptions on some variables}

Before the growth potential of China's insurance industry during the period of 20062020 can be calculated, it is important to estimate the ranges of some relevant variables, including GDP, BRIP for both life and non-life insurance, as well as exchange rate and price index.

\section{Assumptions on GDP}

Although all economists do not agree on the exact value of China's GDP growth rate during the period 2006-2020, some economists share similar opinions. Liu, ${ }^{6}$ for

\footnotetext{
${ }^{6}$ Liu (2006).
} 
example, believes that, excluding the possibility of unforeseen extreme domestic and international events, China's GDP growth rate will continue at 8-9 percent during the period of 2001-2010, and 7-8 percent during the period of 2011-2020. Qiu ${ }^{7}$ applies three different methods (the HP filter approach, the Philips Equation approach and the Production Function approach) to estimate China's potential GDP growth rate in the following 15 years, and points out that 7-9 percent is a possible range for China's GDP growth in the future. Fan ${ }^{8}$ estimates that China's economic growth rate in the following 15 years will be 6-9 percent.

Based on the above-mentioned research and data on China's recent economic growth, this paper applies three estimates for China's annual GDP growth rate during the period of 2006-2020: the conservative estimate of 6 percent, the median estimate of 7.5 percent and the optimistic estimate of 9 percent. In the conservative case, China's GDP will be US\$ 4,120.7 billion in 2020, and GDP per capita US\$ 2,822 dollars. ${ }^{9}$ In the median case, China's GDP will be US\$ 5,087.6 billion in 2020, and GDP per capita US\$ 3,485 dollars. In the optimistic case, China's GDP will be US\$ 6,263.0 billion in 2020, and GDP per capita US\$ 4,290 dollars. All these figures are at 1990 prices.

\section{Benchmark Ratio of Insurance Penetration (BRIP)}

\section{The definition of BRIP}

The BRIP is a measure of the relative development of a country's insurance industry. The BRIP evaluates the relationship between a country's insurance penetration and the world's average penetration (at an economic development level equal to that of the country). If we define "the world average penetration at the same economic development level" as "benchmark penetration", a country's BRIP can be calculated as:

$$
B R I P=\frac{\text { actual penetration }}{\text { benchmark penetration }} \times 100 \%
$$

The denominator, "benchmark penetration", refers to "the world average penetration at the country's economic development level", and the numerator, "actual penetration", refers to the country's actual penetration. If BRIP equals 1, then the country's actual penetration is equal to the world average penetration at that country's economic development level. If BRIP is less than 1, then the actual penetration is less than the world average level. If the BRIP is greater than 1, then the actual penetration is greater than the world average level.

However, it is important to note that the fact that BRIP is greater than 1 does not necessarily mean a large potential for insurance growth. Similarly, if BRIP is less than 1 , the insurance growth potential is not necessarily small. The underlying reason is that each country has its own specific characteristics, and the only factors that can be used

\footnotetext{
${ }^{7}$ Qiu (2006).

${ }^{8}$ Fan (2007).

${ }^{9}$ According to the prediction by the National Population and Family Planning Commission of China (2005), in 2020 China's population may be as high as 1.46 billion.
} 
to forecast the growth potential of an insurance industry are the previous path of the BRIP as well as the data on a country's economic and insurance development.

\section{Estimation of BRIP 2006-2020}

As for China's BRIP, we will analyze life insurance BRIP and non-life insurance BRIP separately. Taking into consideration the trend of life and non-life BRIP during the period of 1980-2005 (BRIP is generally rising, but the growth rate is slowing down ${ }^{10}$ ) as well as the reality of China's life insurance and non-life insurance industry, we set up a second-order autoregressive model to predict China's life and non-life BRIP. ${ }^{11}$

Based on the estimated life and non-life BRIP, ${ }^{12}$ we are able to make predictions of China's BRIP in 2020: China's life BRIP would be 2.31, and non-life BRIP would be 0.93 .

\section{Assumption on price index}

Data on price index used in this paper are obtained from two different sources: First, the data during the period 1980-2005 are either the comparable prices (such as 1990 prices) or the indirect comparable prices adjusted by price index. ${ }^{13}$ Second, for the data during the period of 2006-2020, as we focus on the real value instead of the nominal value, the comparable price is set at the 2005 level, which will facilitate the calculation of the real growth rate of China's insurance industry in the mid and long term.

\section{Assumptions on exchange rate}

The average annual market exchange rate in 2005 is that 1 US $\$=8.19$ Yuan, and we assume that the exchange rate during the period of 2006-2020 remains at this level. This simplification will not have much influence on the conclusion: on the one hand, the main data applied here are all relative data; on the other hand, the focus of this paper is to evaluate China's insurance growth tendency during the period of 20062020 compared with the situation in the base period of 2005. Therefore, such a simplification is helpful in eliminating the influences imposed by the exchange rate fluctuations and revealing the intrinsic growth tendency of China's insurance industry.

${ }^{10}$ Because of limitation on length, the particular measurement and figures about China's BRIP are omitted.

${ }^{11}$ The model is as follows: $B R I P_{t}=\alpha_{0}+\alpha_{1} \ln Y E A R+\alpha_{2} B R I P_{t-1}+\alpha_{3} B R I P_{t-2}+\varepsilon_{t}$. In the equation, BRIP is Benchmark Ratio of Insurance Penetration; YEAR denotes the year; $\varepsilon$ is disturbance; $\alpha_{0}, \alpha_{1}, \alpha_{2}$ and $\alpha_{3}$ are parameters. The lag period is determined mainly by Akaike's information criterion (AIC) as well as a "simple-to-general approach" introduced by Greene (2003), and we also take into account the reality of China's Insurance development. For the reason why we follow AIC, please see also Liew (2004). According to Liew (2004), in the case of small samples, AIC and FPE (final prediction error) are superior to other criteria for estimating the lag period.

12 The estimation results are omitted here.

13 The data on comparable price and price index are taken from the National Accounts Main Aggregates Database provided by United Nations and the data proclaimed by the National Statistical Bureau. 


\section{A preliminary estimation based on the "Market Exchange Rate" approach}

In this section, based on data under the market exchange rate approach, the aforementioned world insurance growth curve in the section on the world insurance growth model, as well as the assumptions in the previous section, the growth potential of China's insurance industry during the period 2006-2020 is estimated and analyzed. We will first analyze the life insurance industry, then the non-life insurance industry, and finally the insurance industry as a whole.

An analysis of the growth of China's life insurance 2006-2020

The calculations here follow the above-mentioned method to measure the growth potential of China's life insurance industry during the period 2006-2020. The results are presented in Table 2. The explanation of the process is as follows. The first row and the second row are, respectively, GDP and GDP per capita. The third row is the theoretical life penetration, which is derived from the world insurance growth curve. The fourth row is the estimated life penetration, which is equal to the product of the theoretical life penetration in the third row and the BRIP derived in the section on the world insurance growth model. The fifth row is the premium in real prices, which is the product of the first row and the fourth row, with prices converting from 1990 prices into 2005 prices. The sixth row uses the actual premium of 2005 and the estimated premium of 2020 in the fifth row to calculate the annual growth rate of life premium during the period of 2006-2020.

Table 2 Estimates of China's life insurance premium by market exchange rate method (2006-2020)

\begin{tabular}{|c|c|c|c|c|c|}
\hline \multirow[t]{2}{*}{ Column } & \multirow[t]{2}{*}{ Item } & \multirow[b]{2}{*}{2005} & \multirow{2}{*}{$\begin{array}{l}\text { Conservative } \\
\text { (GDP growth } \\
\text { rate } 6 \%) \\
2020\end{array}$} & \multirow{2}{*}{$\begin{array}{c}\text { Median } \\
\text { (GDP growth } \\
\text { rate } 7.5 \%) \\
2020\end{array}$} & \multirow{2}{*}{$\begin{array}{c}\begin{array}{c}\text { Optimistic } \\
(\text { GDP growth } \\
\text { rate } 9 \%)\end{array} \\
2020\end{array}$} \\
\hline & & & & & \\
\hline (1) & $\begin{array}{l}\text { GDP (billion } \\
\text { US\$, } 1990 \text { prices) }\end{array}$ & $1,719.4$ & $4,120.7$ & $5,087.6$ & $6,263.0$ \\
\hline (2) & $\begin{array}{l}\text { GDP per capita } \\
\text { (US\$, } 1990 \text { prices) }\end{array}$ & 1,333 & 2,822 & 3,485 & 4,290 \\
\hline (3) & Theoretical penetration & $0.86 \%$ & $1.01 \%$ & $1.09 \%$ & $1.18 \%$ \\
\hline (4) & Estimated penetration & $1.77 \%$ & $2.34 \%$ & $2.51 \%$ & $2.73 \%$ \\
\hline$(5)$ & $\begin{array}{l}\text { Comparable premium } \\
\text { (billion Yuan, } 2005 \text { prices) }\end{array}$ & 324.43 & 968.3 & $1,282.5$ & $1,715.5$ \\
\hline (6) & $\begin{array}{l}\text { Annual growth } \\
\text { rate } 2006-2020\end{array}$ & - & $7.6 \%$ & $9.6 \%$ & $11.7 \%$ \\
\hline
\end{tabular}

Note: The data of 2005 are the actual figures. The data of 2020 are estimation results. It is assumed that 1 US $\$=8.19$ Yuan. The data are rounded.

Data resources: National Accounts Main Aggregates Database provided by the United Nations; the official website of the National Statistical Bureau; the Sigma database provided by Swiss Re; calculation by authors. 
An analysis of the growth of China's non-life insurance 2006-2020

Similar to the estimations above, the growth of China's non-life insurance in the period 2006-2020 is estimated and analyzed in Table 3.

The analysis of the growth of China's whole insurance industry 2006-2020

Based on the analysis of China's life insurance and non-life insurance, the total premium of China's insurance industry during the period of 2006-2020 is estimated and analyzed in Table 4.

As shown in Table 4, during the period of 2006-2020, in the case of a 6 percent GDP growth rate, the average annual growth rate of China's life, non-life insurance and the

Table 3 Estimates of China's non-life insurance premium by market exchange rate method (2006-2020)

\begin{tabular}{|c|c|c|c|c|c|}
\hline \multirow[t]{2}{*}{ Column } & \multirow[t]{2}{*}{ Item } & & $\begin{array}{l}\text { Conservative } \\
(\text { GDP growth } \\
\text { rate } 6 \%)\end{array}$ & $\begin{array}{c}\text { Median (GDP } \\
\text { growth rate } \\
7.5 \%)\end{array}$ & $\begin{array}{l}\text { Optimistic } \\
\text { (GDP growth } \\
\text { rate } 9 \%)\end{array}$ \\
\hline & & 2005 & 2020 & 2020 & 2020 \\
\hline (1) & $\begin{array}{l}\text { GDP (billion } \\
\text { US\$, } 1990 \text { prices) }\end{array}$ & $1,719.4$ & $4,120.7$ & $5,087.6$ & $6,263.0$ \\
\hline (2) & $\begin{array}{l}\text { GDP per capita } \\
\text { (US\$, } 1990 \text { prices) }\end{array}$ & 1,333 & 2,822 & 3,485 & 4,290 \\
\hline (3) & Theoretical penetration & $1.19 \%$ & $1.38 \%$ & $1.47 \%$ & $1.58 \%$ \\
\hline (4) & Calculated penetration & $0.92 \%$ & $1.30 \%$ & $1.38 \%$ & $1.48 \%$ \\
\hline (5) & $\begin{array}{l}\text { Comparable premium } \\
\text { (billion Yuan, } 2005 \text { prices) }\end{array}$ & 168.3 & 535.1 & 702.7 & 927.7 \\
\hline (6) & $\begin{array}{l}\text { Annual growth rate } \\
2006-2020\end{array}$ & - & $8.0 \%$ & $10.0 \%$ & $12.1 \%$ \\
\hline
\end{tabular}

Note: The data of 2005 are the actual figures. The data of 2020 are estimation results. It is assumed that 1 $\mathrm{USS}=8.19$ Yuan. The data are rounded.

Data resources: National Accounts Main Aggregates Database provided by the United Nations; the official website of the National Statistical Bureau; the Sigma database provided by Swiss Re; calculation by author.

Table 4 Estimates of China's total insurance premium by market exchange rate method (2006-2020) (Billion Yuan)

\begin{tabular}{|c|c|c|c|c|c|c|c|c|c|}
\hline \multirow[t]{2}{*}{ Item } & \multicolumn{3}{|c|}{$\begin{array}{l}\text { Conservative } \\
\text { (GDP growth } \\
\text { rate } 6 \% \text { ) }\end{array}$} & \multicolumn{3}{|c|}{$\begin{array}{c}\text { Median } \\
\text { (GDP growth } \\
\text { rate } 7.5 \%)\end{array}$} & \multicolumn{3}{|c|}{$\begin{array}{l}\text { Optimistic } \\
\text { (GDP growth } \\
\text { rate } 9 \%)\end{array}$} \\
\hline & Life & Non-life & Total & Life & Non-life & Total & Life & Non-life & Total \\
\hline Premium of 2005 & 324.4 & 168.3 & 492.7 & 324.4 & 168.3 & 492.7 & 324.4 & 168.3 & 492.7 \\
\hline $\begin{array}{l}\text { Comparable } \\
\text { premium of } 2020 \\
(2005 \text { prices })\end{array}$ & 968.3 & 535.1 & $1,503.3$ & $1,282.5$ & 702.7 & $1,985.2$ & $1,715.5$ & 927.7 & $2,643.2$ \\
\hline $\begin{array}{l}\text { Annual growth } \\
\text { rate } 2006-2020\end{array}$ & $7.6 \%$ & $8.0 \%$ & $7.7 \%$ & $9.6 \%$ & $10.0 \%$ & $9.7 \%$ & $11.7 \%$ & $12.1 \%$ & $11.8 \%$ \\
\hline
\end{tabular}


insurance industry as a whole will be $7.6,8.0$ and 7.7 percent, respectively. In the case of a 7.5 percent GDP growth rate, the average annual growth rate of China's life, nonlife insurance and insurance industry as a whole will be 9.6, 10.0 and 9.7 percent, respectively. In the case of a 9 percent GDP growth rate, the average annual growth rate of China's life, non-life insurance and insurance industry as a whole will be 11.7, 12.1 and 11.8 percent, respectively.

\section{A modified estimation considering "PPP"}

In the last three sections, the "Market Exchange Rate Method" has been applied to convert the local currency into US\$. Theoretically, the market exchange rate method considers the real exchange rate in an international market, and is a reasonable way to depict the reality. However, some researchers ${ }^{14}$ hold the opinion that the market exchange rate tends to underestimate the real exchange rate of RMB to the US\$, that is, the market exchange rate method would underestimate China's real GDP per capita and thus the real level of economic development. Consequently, the growth potential of China's insurance industry might be underestimated under the market exchange rate method.

Taking this problem into consideration, we will apply in this section the "PPP Method" to convert the local currency into US\$ and will calculate the growth potential for China's life insurance, non-life insurance and insurance industry as a whole based on the converted data. In terms of doing this, we would obtain two sets of estimation results, respectively following the "Market Exchange Rate Method" and "PPP Method". Then we could compare the two sets of results and obtain the average value, which would be considered to be a more reasonable foundation for the evaluation of China's insurance growth potential during the period of 2006-2020.

To modify the underestimation mentioned above, in this section, we use all the world countries' GDP data using the "PPP Method". ${ }^{15}$ Based on the analytical framework from the last three sections, we will calculate the growth rate of China's life insurance, non-life insurance and insurance industry, which will in turn be compared with the results obtained by the market exchange rate method, and then be used to calculate the average value, a more comprehensive foundation for the evaluation of the growth rate for China's insurance industry during the period 2006-2020. The specific results are listed in Table 5 .

It can be seen from Table 5 that, as expected, under the PPP method, the growth rates of China's life, non-life and insurance industry as a whole have all increased compared with the results obtained by the market exchange rate method, though they increase to different extents. How, then, should we evaluate the growth potential for China's insurance industry during the period of 2006-2020? From our perspective, there are two factors worth mentioning: On the one hand, due to factors like the regulation of the exchange rate, the market exchange rate method would underestimate China's GDP per capita and in turn the growth potential of China's insurance

\footnotetext{
${ }^{14}$ Wen (2005), for example.

${ }^{15}$ Data resource: Penn World Table from University of Pennsylvania.
} 
industry. On the other hand, due to factors like the failure to distinguish tradable goods and untradable goods, the PPP method would overestimate China's GDP per capita and in turn the growth potential of China's insurance industry. Therefore, the average of the estimates obtained by the market exchange method and PPP method would be more reasonable. Although the estimates obtained by the two methods are both range estimates, the average of the results, which are also range estimates, tends to be a more probable prediction for the growth potential of China's insurance industry.

Accordingly, the value under the conservative assumption in the MER method and that under the optimistic assumption in the PPP method, respectively, constitute the lower and upper limit of a possible range for China's insurance industry growth rate during the period of 2006-2020. After the results obtained by MER method and PPP method will be averaged, the value under the conservative and optimistic assumption will define a more reasonable range for China's insurance industry.

Specifically, as shown in Table 6, during the period of 2006-2020, assuming that China's GDP grows in the range of 6-9 percent per year, a possible range for China's life insurance industry growth rate is 7.6-19.5 percent, and a more reasonable range is 10.3-15.6 percent. As for China's non-life insurance industry, a possible range of growth rate is $8.0-13.8$ percent, and a more reasonable range is $8.8-12.9$ percent. The possible range for China's insurance industry's overall growth rate is 7.7-17.9 percent, with a more reasonable range being $9.8-14.8$ percent.

Table 5 Average annual growth rate of China's insurance industry by market exchange rate method and purchasing power parity method (2006-2020)

\begin{tabular}{|c|c|c|c|c|c|c|c|c|c|}
\hline & \multicolumn{3}{|c|}{$\begin{array}{l}\text { Conservative } \\
\text { (GDP growth } \\
\text { rate } 6 \%)\end{array}$} & \multicolumn{3}{|c|}{$\begin{array}{l}\text { Median } \\
\text { (GDP growth } \\
\text { rate } 7.5 \%)\end{array}$} & \multicolumn{3}{|c|}{$\begin{array}{l}\text { Optimistic } \\
\text { (GDP growth } \\
\text { rate } 9 \%)\end{array}$} \\
\hline & $\begin{array}{l}\text { Life } \\
(\%)\end{array}$ & $\begin{array}{c}\text { Non-life } \\
(\%)\end{array}$ & $\begin{array}{l}\text { Total } \\
(\%)\end{array}$ & $\begin{array}{l}\text { Life } \\
(\%)\end{array}$ & $\begin{array}{c}\text { Non-life } \\
(\%)\end{array}$ & $\begin{array}{c}\text { Total } \\
(\%)\end{array}$ & $\begin{array}{l}\text { Life } \\
(\%)\end{array}$ & $\begin{array}{c}\text { Non-life } \\
(\%)\end{array}$ & $\begin{array}{c}\text { Total } \\
(\%)\end{array}$ \\
\hline $\begin{array}{l}\text { Market Exchange } \\
\text { Rate (MER) } \\
\text { method }\end{array}$ & 7.6 & 8.0 & 7.7 & 9.6 & 10.0 & 9.7 & 11.7 & 12.1 & 11.8 \\
\hline $\begin{array}{l}\text { Purchasing } \\
\text { Power Parity } \\
\text { (PPP) method }\end{array}$ & 13.1 & 9.6 & 12.1 & 16.4 & 11.8 & 15.1 & 19.5 & 13.8 & 17.9 \\
\hline Average & 10.3 & 8.8 & 9.8 & 13.0 & 10.9 & 12.3 & 15.6 & 12.9 & 14.8 \\
\hline
\end{tabular}

Table 6 Intervals for the growth rate of China's Insurance Industry (2006-2020)

\begin{tabular}{lcc}
\hline Item & Possible range (\%) & More reasonable range (\%) \\
\hline Life insurance & $7.6-19.5$ & $10.3-15.6$ \\
Non-life insurance & $8.0-13.8$ & $8.8-12.9$ \\
Insurance industry & $7.7-17.9$ & $9.8-14.8$ \\
\hline
\end{tabular}


Table 7 Estimates of growth rate of China's insurance industry (2006-2020) (Billion Yuan)

\begin{tabular}{|c|c|c|c|c|c|c|c|c|c|}
\hline \multirow[t]{3}{*}{$\begin{array}{l}\text { Average annual } \\
\text { growth rate }\end{array}$} & \multicolumn{3}{|c|}{$\begin{array}{c}\text { Conservative (GDP growth } \\
\text { rate } 6 \% \text { ) }\end{array}$} & \multicolumn{3}{|c|}{$\begin{array}{c}\text { Median }(G D P \text { growth } \\
\text { rate } 7.5 \%)\end{array}$} & \multicolumn{3}{|c|}{$\begin{array}{c}\text { Optimistic }(G D P \text { growth } \\
\text { rate } 9 \%)\end{array}$} \\
\hline & Life & Non-life & Total & Life & Non-life & Total & Life & Non-life & Total \\
\hline & $10.3 \%$ & $8.8 \%$ & $9.8 \%$ & $13.0 \%$ & $10.9 \%$ & $12.3 \%$ & $15.6 \%$ & $12.9 \%$ & $14.8 \%$ \\
\hline \multicolumn{10}{|l|}{2005} \\
\hline Premium & 3,244 & 1,683 & 4,927 & 3,244 & 1,683 & 4,927 & 3,244 & 1,683 & 4,927 \\
\hline Penetration & $1.8 \%$ & $0.9 \%$ & $2.7 \%$ & $1.8 \%$ & $0.9 \%$ & $2.7 \%$ & $1.8 \%$ & $0.9 \%$ & $2.7 \%$ \\
\hline \multicolumn{10}{|l|}{2010} \\
\hline Premium & 5,304 & 2,569 & 7,873 & 5,975 & 2,825 & 8,800 & 6,698 & 3,091 & 9,789 \\
\hline Density & 387 & 188 & 575 & 436 & 206 & 642 & 489 & 226 & 714 \\
\hline Penetration & $2.3 \%$ & $1.1 \%$ & $3.4 \%$ & $2.4 \%$ & $1.1 \%$ & $3.6 \%$ & $2.5 \%$ & $1.2 \%$ & $3.7 \%$ \\
\hline \multicolumn{10}{|l|}{2015} \\
\hline Density & 613 & 277 & 890 & 778 & 335 & 1,113 & 978 & 401 & 1,379 \\
\hline Penetration & $2.8 \%$ & $1.3 \%$ & $4.1 \%$ & $3.1 \%$ & $1.3 \%$ & $4.4 \%$ & $3.4 \%$ & $1.4 \%$ & $4.8 \%$ \\
\hline \multicolumn{10}{|l|}{2020} \\
\hline Premium & 14,174 & 5,989 & 20,162 & 20,269 & 7,960 & 28,229 & 28,544 & 10,427 & 38,970 \\
\hline Density & 971 & 410 & 1,381 & 1,388 & 545 & 1,933 & 1,955 & 714 & 2,669 \\
\hline Penetration & $3.4 \%$ & $1.5 \%$ & $4.9 \%$ & $4.0 \%$ & $1.6 \%$ & $5.6 \%$ & $4.6 \%$ & $1.7 \%$ & $6.3 \%$ \\
\hline
\end{tabular}

Note: All data are in the comparable 2005 prices; health insurance and accident insurance are counted as non-life insurance; "Average annual Growth Rate" is the average of the results obtained from market exchange rate method and purchasing power parity method; Density = Premium/Population,

Penetration $=$ Premium/GDP; the population data come from the prediction for 2010 and 2020 by the National Population and Family Planning Commission of China.

Data resources: the official website of the National Statistical Bureau; the official website of the National Population and Family Planning Commission of China; the data calculated above; calculation by authors. 


\section{Size of China's insurance market by 2020}

Based on the above analysis, we can make a more specific calculation for the growth rate and size of China's insurance industry during the period of 2006-2020. Two sets of figures will be calculated: one is the growth rate and size of the Chinese insurance industry by 2020 , and the other is the relative size of China's insurance industry compared with the world market by 2020 .

\section{Growth rate and size of China's insurance industry}

For the analysis of the growth rate and size of China's insurance industry, premium, insurance density and insurance penetration are selected as three indicators, and 2005, 2010, 2015 and 2020 are selected as the time points. The results of insurance penetration in those years are listed in Table 7.

One can see in Table 7 that in the median scenario, the average annual real growth rate for China's insurance industry during the period of 2006-2020 would be 12.3 percent. In 2010, 2015 and 2020, the premium of China's insurance would, respectively, be $1.8,3.2$ and 5.7 times that of 2005, and the insurance penetration would be 3.6, 4.4 and 5.6 percent, respectively. Figure 3 shows the results of China's insurance penetration in selected years with an S-curve. One important economic explanation for the expected rapid increase in insurance penetration in China relates to the distribution of national income (GDP), which has been very wide in China. There is a significant and fast growing segment of the population with income levels and insurance spending potential approaching that found in the most developed western economy, but the vast majority of the population is rural, with very low incomes and low insurance spending capability. Part of the explanation of the forecast increase in insurance penetration is an expected trend increase in the more wealthy segments of the population and a narrowing in the distribution of national income. In addition, the Chinese government has been encouraging the growth of the insurance industry,

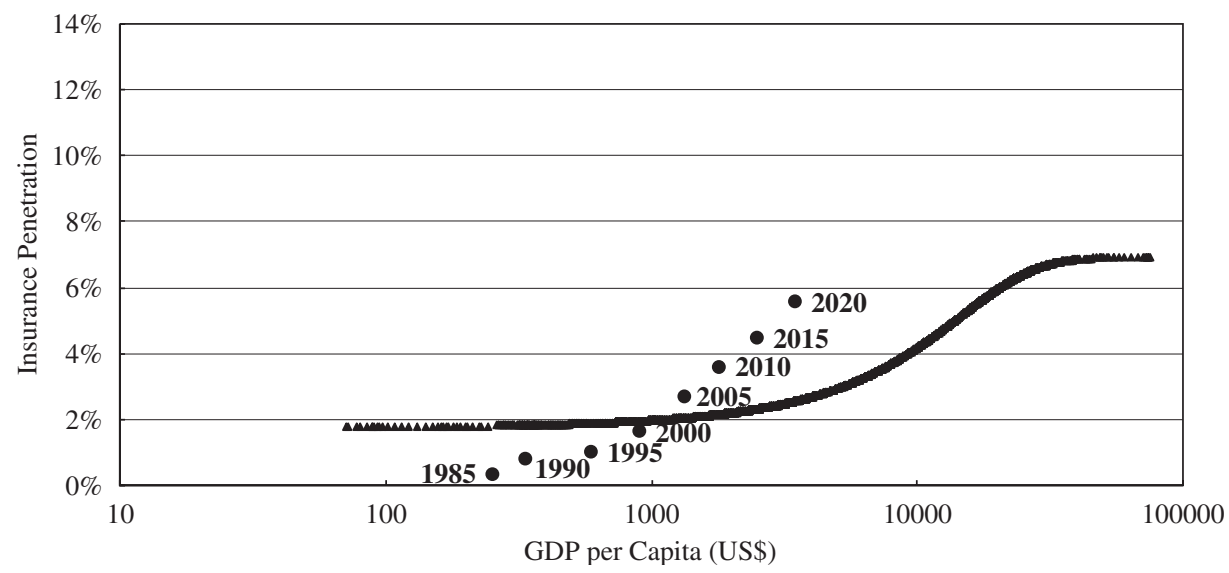

Figure 3. Estimates of China's insurance penetration. 
Table 8 Estimates of relative size of China's insurance industry to the world market (Billion US\$)

\begin{tabular}{|c|c|c|c|c|c|c|c|c|c|}
\hline \multirow[t]{3}{*}{$\begin{array}{l}\text { Average annual } \\
\text { growth rate }\end{array}$} & \multicolumn{3}{|c|}{$\begin{array}{c}\text { Conservative (GDP growth } \\
\text { rate } 6 \% \text { ) }\end{array}$} & \multicolumn{3}{|c|}{$\begin{array}{c}\text { Median }(G D P \text { growth } \\
\text { rate } 7.5 \%)\end{array}$} & \multicolumn{3}{|c|}{$\begin{array}{c}\text { Optimistic }(G D P \text { growth } \\
\text { rate } 9 \%)\end{array}$} \\
\hline & Life & Non-life & Total & Life & Non-life & Total & Life & Non-life & Total \\
\hline & $10.3 \%$ & $8.8 \%$ & $9.8 \%$ & $13.0 \%$ & $10.9 \%$ & $12.3 \%$ & $15.6 \%$ & $12.9 \%$ & $14.8 \%$ \\
\hline \multicolumn{10}{|l|}{2005} \\
\hline China premium & 40 & 21 & 60 & 40 & 21 & 60 & 40 & 21 & 60 \\
\hline China's share & $2.0 \%$ & $1.4 \%$ & $1.7 \%$ & $2.0 \%$ & $1.4 \%$ & $1.7 \%$ & $2.0 \%$ & $1.4 \%$ & $1.7 \%$ \\
\hline \multicolumn{10}{|l|}{2010} \\
\hline China premium & 65 & 31 & 96 & 73 & 34 & 108 & 142 & 38 & 120 \\
\hline World premium & 2,847 & 1,799 & 4,646 & 2,847 & 1,799 & 4,646 & 2,847 & 1,799 & 4,646 \\
\hline China's share & $2.3 \%$ & $1.7 \%$ & $2.1 \%$ & $2.6 \%$ & $1.9 \%$ & $2.3 \%$ & $5.0 \%$ & $2.1 \%$ & $2.6 \%$ \\
\hline \multicolumn{10}{|l|}{2015} \\
\hline World premium & 4,046 & 2,244 & 6,289 & 4,046 & 2,244 & 6,289 & 4,046 & 2,244 & 6,289 \\
\hline China's share & $2.6 \%$ & $2.1 \%$ & $2.4 \%$ & $3.3 \%$ & $2.6 \%$ & $3.1 \%$ & $4.2 \%$ & $3.1 \%$ & $3.8 \%$ \\
\hline \multicolumn{10}{|l|}{2020} \\
\hline China premium & 173 & 73 & 246 & 247 & 97 & 345 & 348 & 127 & 476 \\
\hline World premium & 5,749 & 2,798 & 8,548 & 5,749 & 2,798 & 8,548 & 5,749 & 2,798 & 8,548 \\
\hline China's share & $3.0 \%$ & $2.6 \%$ & $2.9 \%$ & $4.3 \%$ & $3.5 \%$ & $4.0 \%$ & $6.1 \%$ & $4.5 \%$ & $5.6 \%$ \\
\hline
\end{tabular}

Note: All data are in the comparable 2005 prices; health insurance and accident insurance are counted as non-life insurance; "Average annual Growth Rate" is the average of the results obtained from market exchange rate method and purchasing power parity method.

Data resources: the official website of the National Statistical Bureau; the Sigma database provided by Swiss Re; the Economist Intelligence Unit's report

"Foresight 2020"; the United Nations' report "World Population to 2300"; the data calculated above; calculation by author. 
with state-owned enterprises purchasing insurance rather than self-insuring, which contrasts with many other countries at a similar level of their development. In life insurance, there is also strong government support for private sector saving and for a greater level of individual self-reliance, and this is also evidenced by a social security system that is less pervasive in other countries at a similar level of development. Hence, China is expected to have a BRIP greater than 1 . These underlying trends are implicit in the data used in the model.

\section{Relative size of China's insurance industry to the world market}

Combining the above analytical framework with data from "Foresight 2020" (Economist Intelligence Unit), "World Population to 2300"(United Nations) and "Sigma Premium Database" (Swiss Re), we estimate that the average annual growth rates of world life insurance, world non-life and world insurance industry during the period of 2006-2020 are, respectively, 7.3, 4.5 and 6.3 percent. In comparison, the growth rate of China's insurance industry ( 12.3 percent) would almost double that of the world average ( 6.3 percent). Table 8 indicates the relative size of China's insurance market compared with that of the world.

In the median scenario, as indicated in Table 8, the market share of China's insurance industry in the world would be $2.3,3.1$ and 4.0 percent, respectively, in 2010, 2015 and 2020. In consideration of the fact that China was the ninth largest insurance market in the world in 2006, we expect that China will enhance the ranking in 2020 and probably be the sixth largest insurance market, especially if the RMB will be revaluated before 2020 .

\section{Conclusion}

Based on a large amount of historical data, we examined the world insurance growth curve using the "Market Exchange Rate Method" and "PPP Method". Based on this curve as well as the reality of China's national economy and insurance industry, we quantitatively estimated the growth potential for China's life insurance, non-life insurance and insurance industry as a whole during the period of 2006-2020.

The main conclusions of this paper are as follows:

During the period of 2006-2020, assuming that China's GDP grows 6-9 percent per year, the possible range of China's insurance industry growth rate is 7.7-17.9 percent, and a more reasonable range is $9.8-14.8$ percent.

In the median scenario, the average annual real growth rate for China's insurance industry during the period of 2006-2020 would be 12.3 percent. In 2020, the premium levels for China's insurance market would be 5.7 times higher than in 2005, and the insurance penetration would be 5.6 percent, with 4 percent for life insurance and 1.6 percent for non-life insurance.

The growth rate of China's insurance industry during the period of 2006-2020 (12.3 percent) would almost double that of the world average (6.3 percent). In 2020, the market share of China's insurance industry in the world would be 4.0 percent.

Finally, three points about this paper should be emphasized. First, the growth rates discussed in this paper are in real term instead of nominal term. In other words, these 
rates are based on comparable prices, excluding the influence of inflation. Second, health insurance and accident insurance can be classified into either life or non-life insurance; however, in this paper, they are counted as part of non-life insurance (one should note this when citing the conclusions of this paper). Third, other empirical studies show that the growth and size of the insurance industry are closely related in the long term to overall economic development. There are clearly other factors social, demographic, cultural, political and market structure - that also have an impact, but the key drivers in the long term are economic, hence our focus on GDP as a proxy measure for overall economic development. It is assumed in the paper that the average annual growth rate of China's GDP will be 6-9 percent during the period of 2006-2020. It should be mentioned, however, that if the GDP growth rate lies out of this range then the conclusions would have to be adjusted accordingly. Nevertheless, even if the GDP of China falls below 6 percent, it is still likely to be above the global average level and the size of the Chinese insurance market will still be one of the world's largest.

\section{References}

Beenstock, M., Dickinson, G.M. and Khajuria, S. (1986) 'Determination of life premiums: An international cross section analysis 1970-81', Insurance: Mathematics and Economics 5: 261-270.

Beenstock, M., Dickinson, G.M. and Khajuria, S. (1988) 'The relationship between propertyliability insurance premiums and income: An international analysis', Journal of Risk and Insurance 55: $259-272$.

Carter, R.L. and Dickinson, G.M. (1992) Obstacles to the Liberalisation of Trade in Insurance (see Appendix), London: Harvester Wheatsheaf.

Economist Intelligence Unit (2006) 'Foresight 2020: Economic, industry and corporate trends', from http:// www.eiu.com/foresight2020, accessed 16 June 2007.

Enz, R. (2000) 'The S-curve relation between per-capita income and insurance penetration', Geneva Papers on Risk and Insurance 25: 396-406.

Fan, G. (2007) 'China's economic growth rate will be 6-9 percent in the following fifteen years', from http:// finance.people.com.cn/GB/6530164.html accessed 1 March 2008.

Greene, W.H. (2003) Econometric Analysis, New Jersey: Pearson/Prentice-Hall.

Liew, V.K.S. (2004) 'Which lag length selection criteria should we employ?', Economics Bulletin 3: 1-9.

Liu, W. (2006) 'Historical change of the reform and fundamental transition of the economic growth mode of China', Economic Research Journal 41(1): 4-10.

National population and family planning commission of China (2005) 'Chinese population', from: http:// www.chinapop.gov.cn/rkgk/zgrk2/t20050920_31760.htm accessed 20 September 2005.

Outreville, J.F. (1996) 'Life insurance markets in developing countries', Journal of Risk and Insurance 63: $263-278$.

Qiu, X. (2006) 'Factor analysis and prospects of China's economic growth', Economic Research Journal 41(5): 4-12.

United Nations (2004) 'World population to 2300', from http://www.un.org/esa/population/publications/ longrange2/WorldPop2300final.pdf.

Wen, J. (2005) 'The research on purchasing power parity', Journal of Finance 14(4): 44-56.

\section{About the Authors}

Wei Zheng is Associate Professor and Vice Chair of the Department of Risk Management and Insurance at the School of Economics, Peking University, Beijing, China. He is also Secretary General of China Center for Insurance and Social Security 
Research (CCISSR), Peking University, a member of the Board of Directors of the Insurance Institute of China (IIC) and a member of the Editorial Board of Asia-Pacific Journal of Risk and Insurance (APJRI).

Yongdong Liu is a graduate student at the Center for Chinese Agricultural Policy at the Institute of Geographical Sciences and Natural Resources, Chinese Academy of Sciences, Beijing, China. He obtained a Bachelor's Degree from the Department of Risk Management and Insurance at the School of Economics, Peking University, Beijing, China.

Gerry Dickinson is Professor of international insurance at the Sir John Cass Business School, City of London. He is also currently Vice-Secretary General of The Geneva Association, Chairman of the UK Advisory Board of the China-Europe Financial Exchange, and consultant to the OECD. 